\title{
鋼製剛飛翔体の高速衝突を受ける コンクリート板の局部破壊に関する実験的研究
}

\author{
別府 万寿博 ${ }^{1}$ 三輪 幸治 $^{2} \cdot$ 大野 友則 $^{3} \cdot$ 塩見 昌紀 $^{4}$ \\ 1正会員 防衛大学校講師 建設環境工学科 ( \\ E-mail:beppu@nda.ac.jp \\ 2学生会員 防衛大学校理工学研究科学生 建設環境工学科 (广239-8686 神奈川県横須賀市走水1-10-20) \\ 3正会員 防衛大学校教授 建設環境工学科 (广239-8686 神奈川県横須賀市走水1-10-20) \\ 4正会員日本ゼニスパイプ(株)（テ101-0032 東京都千代田区岩本町1-10-5）
}

本研究は, 鋼製の岡飛翔体がコンクリート板に高速度で衝突した際に生じる局部破壊について検討を行 つたものである。まず，高速衝突実験を行うために，質量 $50 \mathrm{~g} \sim 1000 \mathrm{~g}$ の飛翔体が衝突速度約 $100 \sim 500 \mathrm{~m} / \mathrm{s}$ となる性能を有する高圧空気式発射装置を開発した．次に，この装置を用いて普通および高強度コンクリ 一ト板に対する高速衝突実験を行い, 飛翔体の衝突速度やコンクリート板の板厚・強度の相違が破壊に及 ぼす影響を調べた．実験の結果，衝突速度および板厚の大小によってコンクリートの破壊モードが変化す ることが明らかとなった。 また, 表面破壊, 裏面剥離の破壊プロセスを高速度ビデオカメラで可視化し, 破壊の様子を観察するとともに，破壊が進展する際の条件について考察した.

Key Words : high-velocity impact, concrete, local failure, hard projectile

\section{1.はじめに}

近年，わが国では花火工場等における不測の爆発事 故あるいは世界各地で爆破テロが発生するなど，爆発災 害が増加傾向にある. コンクリート構造物に爆発荷重が 作用すると, 爆風圧による直接的な被害が生じるだけで なく，破壊されたコンクリート塊や金属破片および周囲 の設置物等の破壊片(以下，飛翔体という)が数 100～数 $1000 \mathrm{~m} / \mathrm{s}$ の高速度で飛散し，人命や構造物に対して二次 的被害をもたらすことが報告されている ${ }^{1) 3}$. したがっ て，爆発被害を受ける可能性が高い施設や社会的に重要 な施設は，飛翔体の高速衝突によって過度の局部損傷・ 破壊が生じないように設計される必要がある。しかし, わが国においては，高速飛翔体の衝突に対するコンクリ 一ト構造物の防護設計に関する系統的な研究は少ない. このため，局部破壊を精度よく評価できる実験や解析法 の確立は急務であるといえる.

飛翔体の高速衝突を受けるコンクリートの局部破壊 は, 図-1 に示すように表面破壊, 裏面剥離および貫通 に区分される ${ }^{4)}$. 表面破壊とは，衝突側のコンクリート のみが破壊する現象である，董面剥離は，衝突位置裏側 のコンクリートが破片となって飛散する現象である. 貫
通は，飛翔体が部材を完全に突き抜ける現象であり，防 護上は許容できない破壊である。したがって，構造物内 にいる人体への被害を抑止するためには設計上は少なく とも董面剥離を防止することが求められる.

飛翔体の硬さや剛性によって区別される剛および柔 飛翔体の高速衝突を受けるコンクリートの局部破壊につ いては，これまで世界各国において主に軍事的な目的で 実験研究が行われてきた. とくに，第二次世界大戦前後 には多数の実験が行われ，米国では修正 NDRC 式や

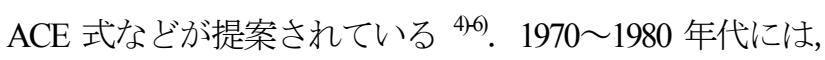
日本においても飛来物に対する原子力発電関連施設の安 全性に関して検討が行われている. 電力中央研究所では, 質量が数 $\mathrm{kg}$ 数 $100 \mathrm{~kg}$ の剛飛翔体を鉄筋コンクリート版 に衝突させ，表面破壊深さおよび裏面剥離・貫通限界厚

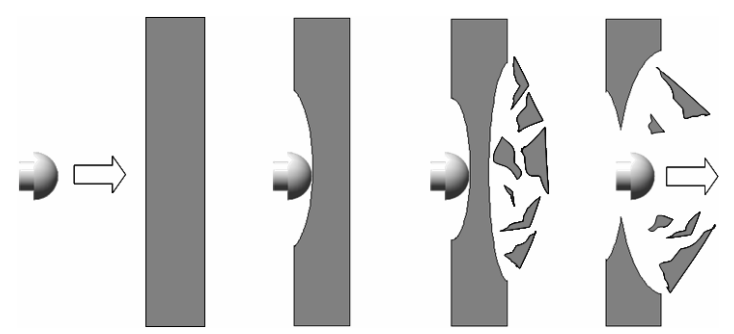

(a)表面破壊 (b)裏面剥離(c)貫通

図-1 局部破壊の種類 


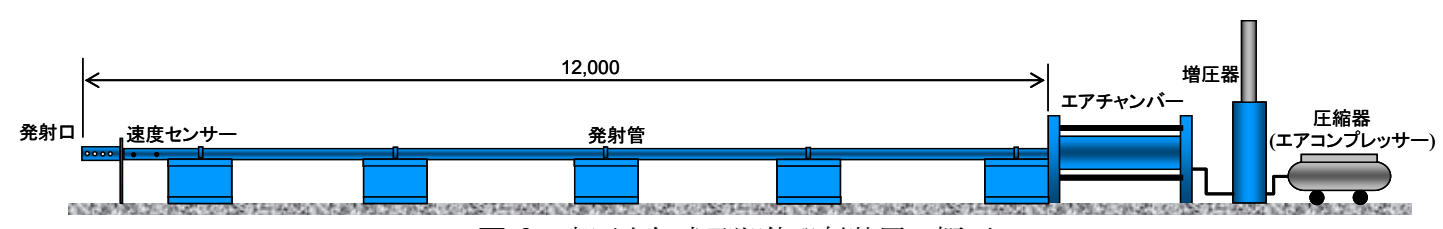

図-2 高圧空気式飛翔体発射装置の概要

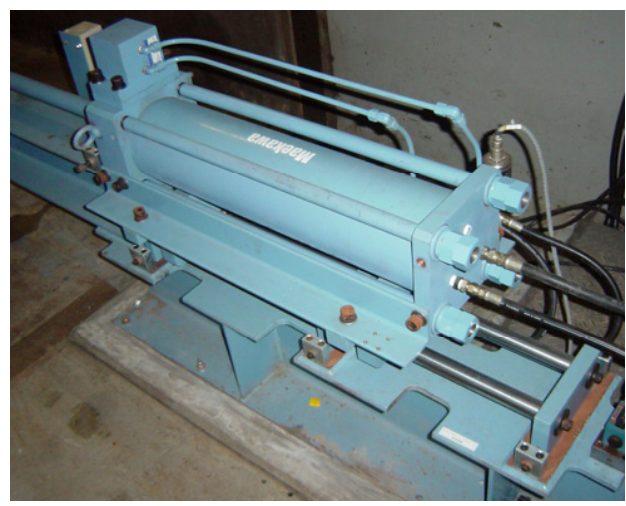

(a)エアチャンバー

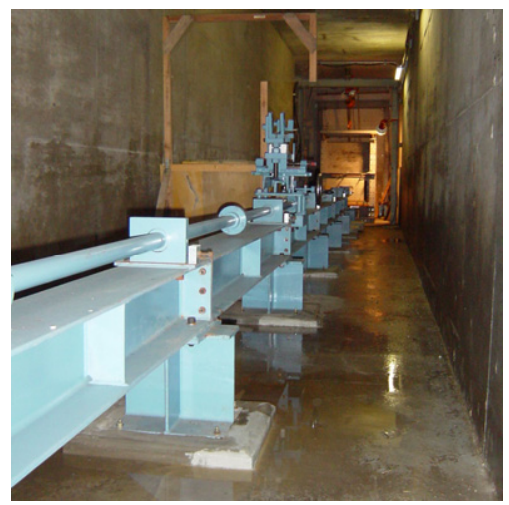

(b) 発射管

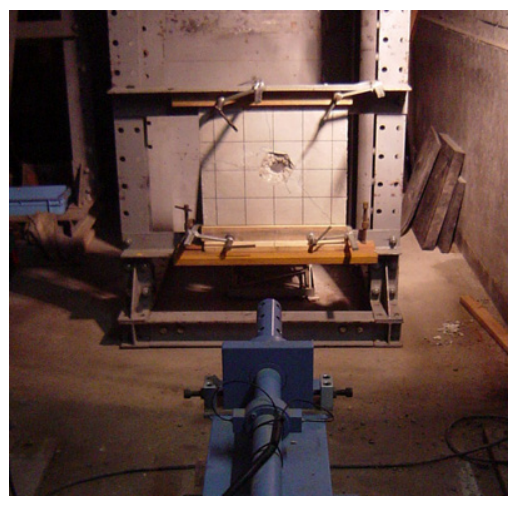

(c) 発射口

写真-1 実験装置各部

の予測式を CRIEPI(電研)式として提案している ${ }^{\text {9-9) }}$ 。ま た, 内田らは変形を伴う柔飛翔体の衝突を受けるコンク リート板の局部破壊問題において, 飛翔体の変形が貫入 深さに及ぼす影響について検討している ${ }^{10), 11) .}$

しかしながら，これまでに提案された種々の局部破 壊評価式は，用いる式によって算定値に大きなばらつき があり 4)の，次のような問題点が指摘されている．すな わち, 既往の評価式は, 次元解析や理論あるいは実験デ 一夕の統計的処理に基づいて変数や係数の決定が行われ ている 4), 12), 13)が，これらのパラメータが局部破壊に影 響を及ぼす度合が十分には解明されているとは言いがた ( $^{14)}$. また, 過去の実験の中には数十年以上も前に行わ れたものもあり，詳細な実験条件が不明瞭であることか ら実験データには大きなばらつきがある.さらに，今後 の課題としては，既往の実験データが少ない衝突速度が $300 \mathrm{~m} / \mathrm{s}$ を超える場合の破壊挙動や圧縮強度が $100 \mathrm{~N} / \mathrm{mm}^{2}$ を超えるような高強度コンクリートの耐衝撃性について の検討が必要であることが指摘されている ${ }^{14)}$.このよう に, 高速衝突を受けるコンクリートの局部破壊の評価に 関する問題点を解決し，防護設計法の提案を行うために は, 衝突の条件(飛翔体の剛性, 速度, 先端形状および コンクリート強度など)と破壊モードの関係を調べると ともにコンクリートの破壊挙動やメカニズムに関しても 解明する必要があると考えられる. ちなみに, 近年の数 值シミュレーション技術の発達は著しく, 本分野におい ても衝撃専用の解析ッールである LS-DYNA や AUTODYNなどを用いた複雑な解析の試みも行われてい

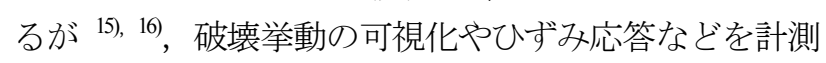
した実験例がほとんどないため, 解析の精度や結果の妥
当性を検証できないのが現状である.

本研究は, このような背景から, 剛飛翔体の高速衝 突を受けるコンクリートの局部破壊について基礎的な実 験を行ったものである. まず，飛翔体の質量が $50 \mathrm{~g} \sim$ $1000 \mathrm{~g}$ の範囲で, 約 $100 \sim 500 \mathrm{~m} / \mathrm{s}$ の衝突速度が得られる 高圧空気式飛翔体発射装置の開発を行った. 次に, 先端 が半球の形状を有する鋼製飛翔体を用いて普通および高 強度コンクリートの板供試体に対寸る衝突実験を行い, 衝突速度に対する板厚と破壊モードの関係を調べた.こ の際, 高速度ビデオカメラによりコンクリートの破壊挙 動を可視化するとともに内部の破壊状況を確認し, 破壊 モードが進展する条件について現象論的な考察を行った.

\section{2. 高圧空気式飛翔体発射装置の開発}

飛翔体発射装置の開発にあたっては, 安全上の観点か ら飛翔体の発射駆動力として圧縮空気を用い, その圧力 調節によって飛翔体の速度を任意に制御する構造にした. 図-2および写真-1に高圧空気式飛翔体発射装置の概要を 示寸. 装置は, 圧縮器(エアコンプレッサー), 増圧器, エアチャンバーおよび発射管(長さ；12m, 内径 ; $35 \mathrm{~mm}$ ) で構成されている. 飛翔体の発射操作は, 以下の手順で 行われる。

(1) 飛翔体を発射管始端のエアチャンバー内に挿入し て油圧により拘束固定する.

(2) エアコンプレッサーで圧縮された空気を増圧器に 送り，これをさらに圧縮する。

(3)増圧された空気がエアチャンバーに送られる. 


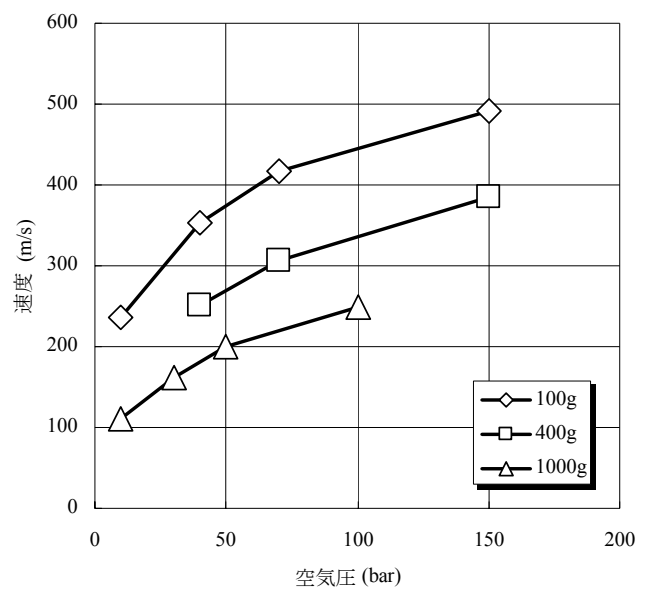

図-3 飛翔体の速度〜空気圧関係

(4) 衝突速度に対応寸る所定の圧力になったら飛翔体 の拘束を解除し，飛翔体を発射する.

発射された飛翔体の速度は, 発射管の出口に設置した レーザー式速度検出センサーで衝突直前の速度を計測す ることができる，このレーザー式速度センサーは， $50 \mathrm{~cm}$ 間隔で2箇所に設置されており，レーザー光を飛 翔体が横切る時間差から速度を求める仕組みになってい る.ちなみに, 計測精度は $1 \mathrm{~cm} / \mathrm{s}$ 単位である。飛翔体の 大きさ, 直径, 長さのうち, 直径寸法は発射管の内径 (35mm)の大きさ以内という制約を受けるが, 最大質量 1000g以内で材料や形状・長さ寸法は任意に調節するこ とができる.

本実験装置の性能を確認寸るために, 飛翔体の質量 を3種類(100g，400gおよび1000g)に変化させて，空気圧 と発射速度の関係を調べた。 なお，試験の実施に際して は, エアチャンバーの耐圧性能上の制約から, 最大空気 圧を150bar とした．図-3に，性能試験から得られた飛翔 体の速度〜空気圧関係を示寸. 質量 $100 \mathrm{~g}$ の飛翔体に対し ては，10barの空気圧で約 $230 \mathrm{~m} / \mathrm{s} の$ 発射速度，150barの空 気圧で約 $500 \mathrm{~m} / \mathrm{s}$ の発射速度である. 質量 $1000 \mathrm{~g}$ の場合で は，10barの空気圧で約 $100 \mathrm{~m} / \mathrm{s} ， 100 \mathrm{bar}$ の空気圧で約 $250 \mathrm{~m} / \mathrm{s}$ 発射速度が得られた。 図-4は, 飛翔体の質量と 発射速度から求めた運動エネルギーを示している。 これ より，質量100gの飛翔体がもつ運動エネルギーの範囲は 約3 12kJ, 質量 $1000 \mathrm{~g}$ の飛翔体の場合は約 $5 \sim 30 \mathrm{~kJ}$ 範囲 であることがわかる。

\section{3. 実験の概要}

\section{（1）飛翔体および供試体}

鋼製飛翔体を写真-2に示寸，飛翔体はナイロン製の固 定具に組み込まれてエアチャンバーに挿入され，その後，

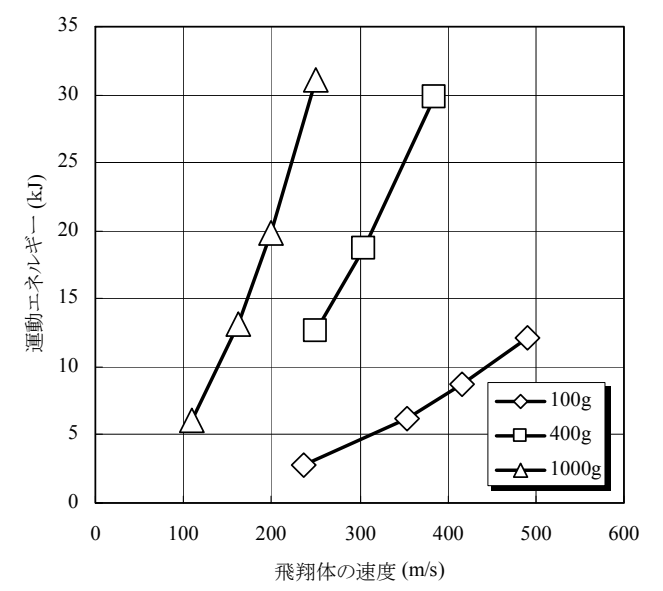

図-4 飛翔体の運動エネルギー〜速度関係

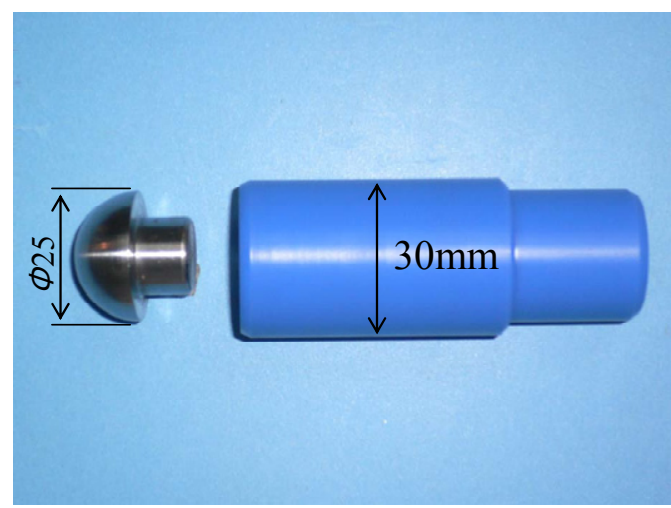

写真-2 飛翔体および固定具

固定具とともに発射される. 用いた飛翔体の諸元は, 材 質 : 鋼材(SS400), 先端形状 : 半球型, 直径 : $25 \mathrm{~mm}$, 質 量 : 50gである.

供試体は, 普通強度(圧縮強度 $25 \mathrm{~N} / \mathrm{mm}^{2}$ )および高強度 (圧縮強度 $100 \mathrm{~N} / \mathrm{mm}^{2}$ ) コンクリートを用いて無筋コンクリ 一ト板供試体を作製した．コンクリートの配合を，表-1 および表-2 に示す.コンクリート板の寸法は縦 $50 \mathrm{~cm} \times$ 横 $50 \mathrm{~cm}$ とし，数種類の板厚を作製した．なお，普通お よび高強度コンクリート板には，供試体搬送中の損傷を 防ぐため補強用鉄筋(D9)を周囲に配置した．コンクリー 卜板は，発射管出口から $1 \mathrm{~m}$ の位置に設置した鋼製支持 具に，上下 2 辺をクランプで垂直に固定した.

\section{（2）実験ケースおよび計測項目}

実験パラメータは, 飛翔体の衝突速度とコンクリート 板の板厚および強度である. 板厚は, 普通強度コンクリ 一トの供試体では $3 \sim 13 \mathrm{~cm}$ 範囲で 8 種類, 高強度コン クリートの供試体では $2 \sim 10 \mathrm{~cm}$ 範囲で 6 種類を作製し た.これらの板厚に対して飛翔体の衝突速度を増加させ, 破壊モードの推移を検討した。 実験後は, 破壊モードを 区分するとともに，表面破壊，裏面剥離の直径と深さを 計測した．また，コンクリート板表面および裏面のひず 
表-1＼cjkstart普通強度コンクリートの配合

\begin{tabular}{|c|c|c|c|c|c|c|c|c|c|}
\hline \multirow{2}{*}{$\begin{array}{c}\text { 粗骨材の最 } \\
\text { 大寸法 } \\
(\mathrm{mm})\end{array}$} & \multirow{2}{*}{$\begin{array}{c}\text { スランプ } \\
(\mathrm{cm})\end{array}$} & \multirow{2}{*}{$\begin{array}{c}\text { 水セメント比 } \\
W / C \\
(\%) \\
\end{array}$} & \multirow{2}{*}{$\begin{array}{c}\text { 空気量 } \\
\text { (\%) }\end{array}$} & \multirow{2}{*}{$\begin{array}{c}\text { 細骨材率 } \\
s a \\
(\%) \\
\end{array}$} & \multicolumn{5}{|c|}{ 単 位 量( $\left(\mathrm{kg}^{\prime} \mathrm{m}^{3}\right)$} \\
\hline & & & & & $\begin{array}{l}\text { 水 } \\
W\end{array}$ & $\begin{array}{c}\text { セメント } \\
C\end{array}$ & $\begin{array}{c}\text { 細骨材 } \\
\quad S\end{array}$ & $\begin{array}{c}\text { 粗骨材 } \\
G\end{array}$ & 混和剤 \\
\hline 20 & 18 & 57 & 5 & 48.8 & 172 & 302 & 874 & 947 & 3.02 \\
\hline
\end{tabular}

表-2＼cjkstart高強度コンクリートの配合

\begin{tabular}{|c|c|c|c|c|c|c|c|c|c|c|c|}
\hline \multirow[b]{2}{*}{$\begin{array}{c}\text { 空気量 } \\
\text { (\%) }\end{array}$} & \multirow[b]{2}{*}{$\begin{array}{c}\text { フロー } \\
(\mathrm{mm})\end{array}$} & \multirow[b]{2}{*}{$\begin{array}{l}W P \\
(\%)\end{array}$} & \multirow{2}{*}{$\begin{array}{c}\text { 細骨材率 } \\
s a \\
(\%) \\
\end{array}$} & \multicolumn{8}{|c|}{ 単 位 量 $\left(\mathrm{kg}^{\prime} \mathrm{m}^{3}\right)$} \\
\hline & & & & $\begin{array}{l}\text { 水 } \\
W\end{array}$ & $\begin{array}{c}\text { セxント } \\
C\end{array}$ & スラグ & $\begin{array}{c}\text { 膨張材 } \\
\text { CSA }\end{array}$ & 混和材 & $\begin{array}{c}\text { 細骨材 } \\
S\end{array}$ & $\begin{array}{c}\text { 粗骨材 } \\
\text { G }\end{array}$ & $\begin{array}{l}\text { 高性能 } \\
\text { 減水㓮 }\end{array}$ \\
\hline 2 & 600 & 22.1 & 40.0 & 150 & 450 & 150 & 30 & 50 & 631 & 964 & 7.48 \\
\hline
\end{tabular}

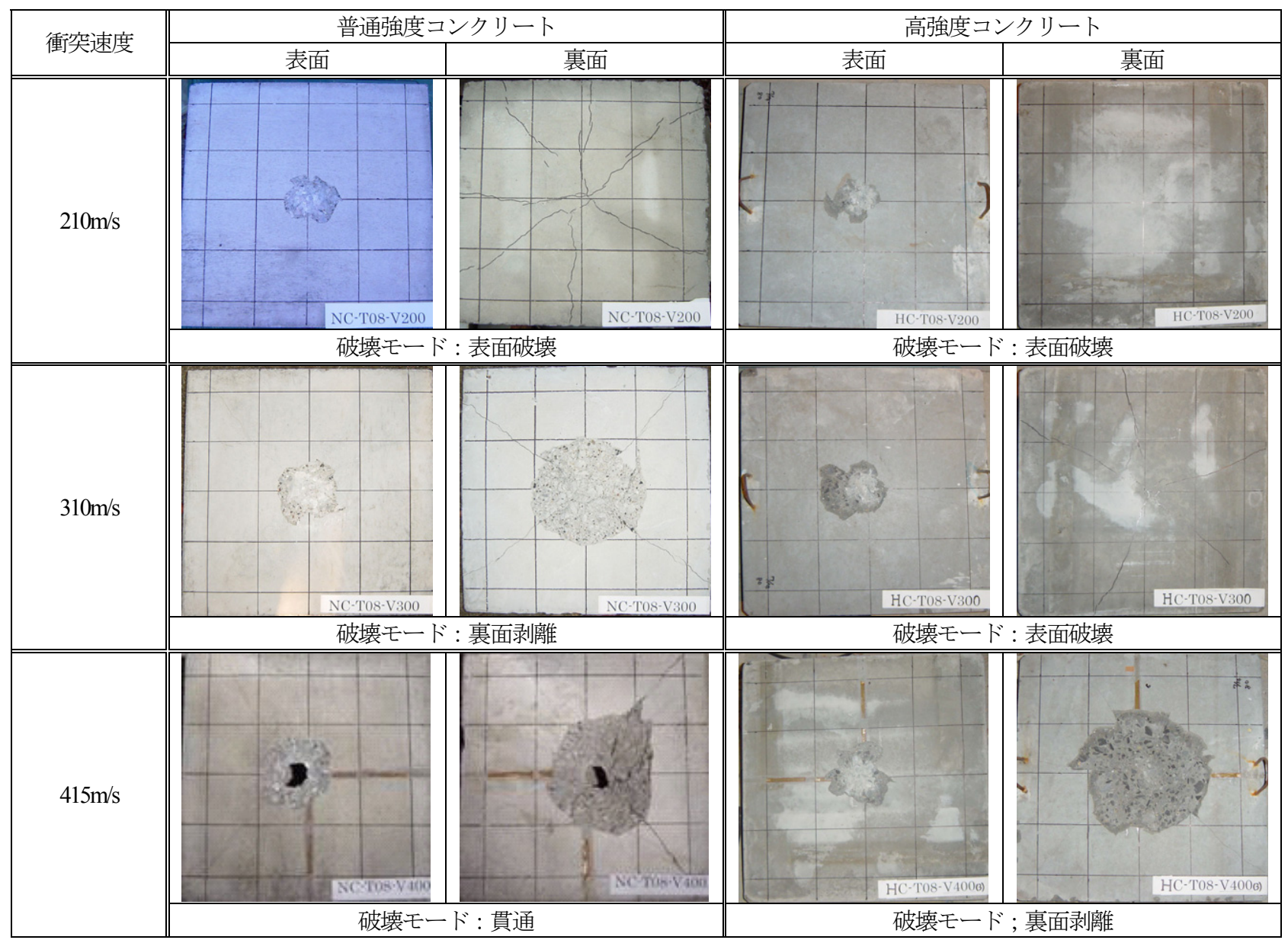

図-5 局部破壊の状況(板厚 $8 \mathrm{~cm}$ )

みをひずみゲージにより計測するとともに，高速度ビデ オカメラで撮影した画像から，破壊の時刻歴挙動を観察 した.

\section{4. 破壊モ一ド}

図-5は，板厚 $8 \mathrm{~cm} の$ 供試体に生じた局部破壊を衝突速 度の大きさに対して示したものである．なお，本実験結 果において貫通孔が生じる場合には，(1)衝突後，図-1の
ように飛翔体が供試体を完全に突き抜ける場合と，(2) 衝突後, 飛翔体自体は供試体を突き抜けることなく跳㪄 返るが，衝突により生じた表面破壊と裏面剥離が連絡し て貫通孔が形成される，ときの 2 通りがあることがわか った。しかしながら実験後の供試体の様子から(1)，(2) のどちらの現象により貫通孔が形成されたかの判別は難 しく, 本実験結果においては(2)の場合も破壊モードは 貫通として判定した. 図-5に示寸普通強度コンクリート の供試体の場合, 衝突速度が約 $210 \mathrm{~m} / \mathrm{s}$ では直径 $10 \mathrm{~cm}$ 程度 の表面破壊が生じた。 また, 速度の増加にともなって 


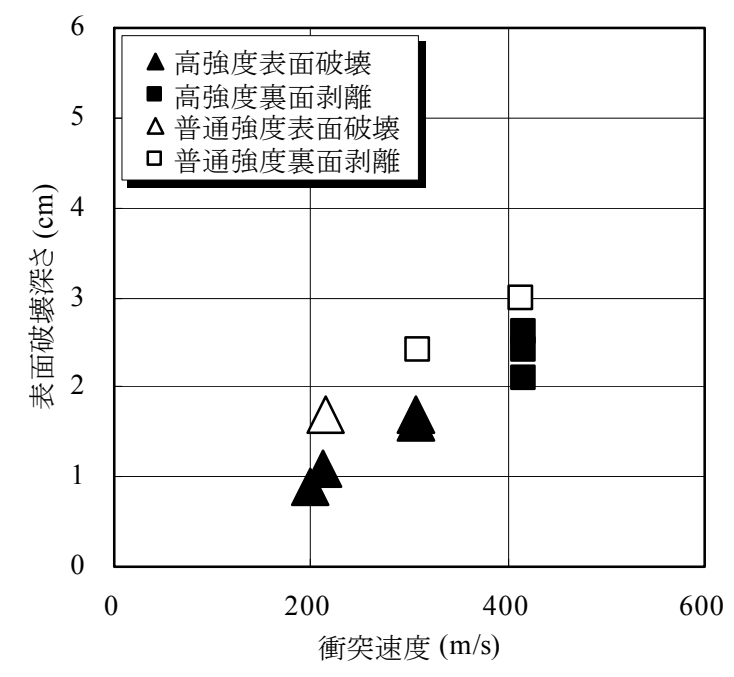

(a) 表面破壊深さ

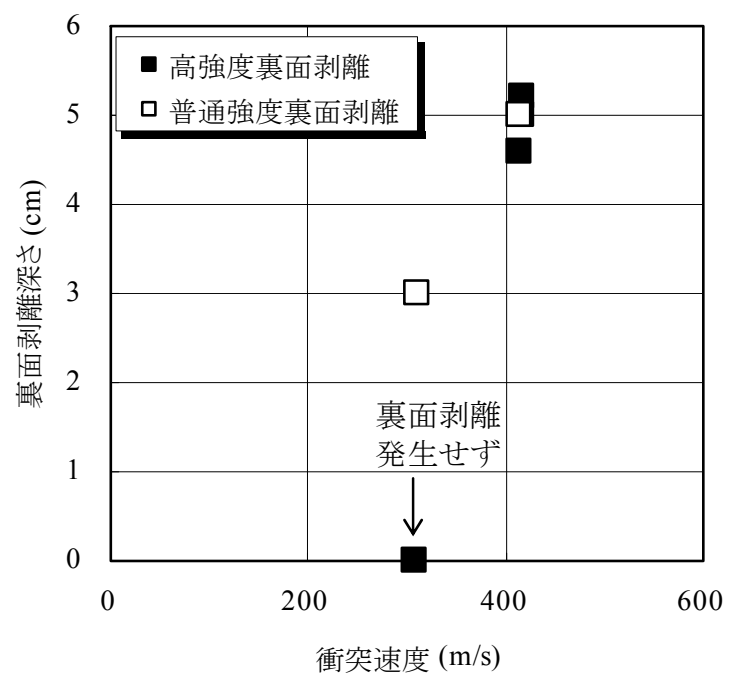

(b) 裏面剥離深さ

図-6 普通および高強度コンクリートの表面および裏面における破壊深さの比較（板厚 $8 \mathrm{~cm}$ )

$310 \mathrm{~m} / \mathrm{s}$ で裏面剥離， $415 \mathrm{~m} / \mathrm{s}$ では貫通へと破壊が大きく生 じていることがわかる，一方，高強度コンクリートでは， 普通強度コンクリートで裏面剥離が生じた衝突速度 $310 \mathrm{~m} / \mathrm{s}$ の場合でも表面破壊しか発生していない.また， 衝突速度 $415 \mathrm{~m} / \mathrm{s}$ の場合は，裏面剥離が生じた。すなわち, コンクリート強度の増加は，局部破壊の大きさの軽減に 対して有効であることがわかる.

図-6は，図-5のケースで生じた普通および高強度コン クリートの表面および裏面の破壊深さを比較して示して いる. 図-6(a)より, 普通強度および高強度コンクリート とも衝突速度の増加にともなって, 表面破壊深さも増加 する傾向を示している．また，高強度コンクリートの表 面破壊深さの方が普通強度コンクリートに比べて $25 \%$ 程 度小さい. すなわち，高強度コンクリートの方が，表面 破壊に対する抵抗力が大きいことがわかる. 一方, 図6(b)の裏面剥離深さより, 衝突速度 $310 \mathrm{~m} / \mathrm{s}$ では, 普通強 度コンクリートは裏面剥離が生じたが, 高強度コンクリ

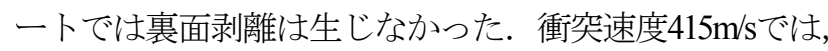
いずれも董面剥離が生じたが，その深さに大きな差は認 められない. すなわち, 裏面剥離に対しても高強度コン クリートの方が発生しにくいと考えられる，なお，表面 破壊および董面剥離については，次章で詳細に考察する. 各実験ケースで得られた破壊モードを，図一7に示す.

図から，普通および高強度コンクリートともに飛翔体の 衝突速度が大きく，また，板厚が小さくなるにしたがっ て, 破壊モードが表面破壊, 裹面剥離, 貫通の順に進展 していることがわかる．また，参考のため，既往の局部 破壊評価式の中で，代表的な修正NDRC式による限界厚 を, 実線(裏面剥離限界厚) と破線(貫通限界厚)で示して いる. 両式は式(1a), (1b), 式(2a), (2b)で表される.

\section{【修正NDRC式】}

1) 裏面剥離限界厚さ

$$
\begin{array}{ll}
s=7.91 x-\left(5.06 x^{2} / D\right) & ; x \leq 0.65 D \\
s=2.12 D+1.36 x & ; x \geq 0.65 D
\end{array}
$$

2)貫通限界厚さ

$$
\begin{aligned}
& e=3.19 x-\left(0.718 x^{2} / D\right) ; x \leq 1.35 D \\
& e=1.32 D+1.24 x \quad ; x \geq 1.35 D
\end{aligned}
$$

ここに， $x$ は表面破壊深さ(cm)で，式(3a)，(3b)で求めら れる。

$$
\begin{aligned}
& x=3.899 \cdot 10^{-3} \sqrt{N W D\left(V_{0} / D\right)^{1.8} / \sqrt{f_{c}^{\prime}}} ; x \leq 2 D \\
& x=\left\{3.787 \cdot 10^{-6} N W\left(V_{0} / D\right)^{1.8} / \sqrt{f_{c}^{\prime}}\right\}+D ; x \geq 2 D
\end{aligned}
$$

$N$ は飛翔体の先端形状に関する係数， $D$ は飛翔体の直 径 $(\mathrm{cm}), V_{0}$ は飛翔体の衝突速度 $(\mathrm{cm} / \mathrm{s}), W$ は飛翔体の質 量 $(\mathrm{kg}), \quad f_{c}^{\prime}$ はコンクリートの圧縮強度 $\left(\mathrm{N} / \mathrm{mm}^{2}\right), \quad s$ は裏 面剥離限界厚さ $(\mathrm{cm}), e$ は貫通限界厚さ $(\mathrm{cm})$ を示す。

図-7(a)の普通強度コンクリートの結果をみると, 飛翔 体の衝突速度が大きく, また, 板厚が小さくなるにした がって破壊モードが進展する傾向については，実験と修 


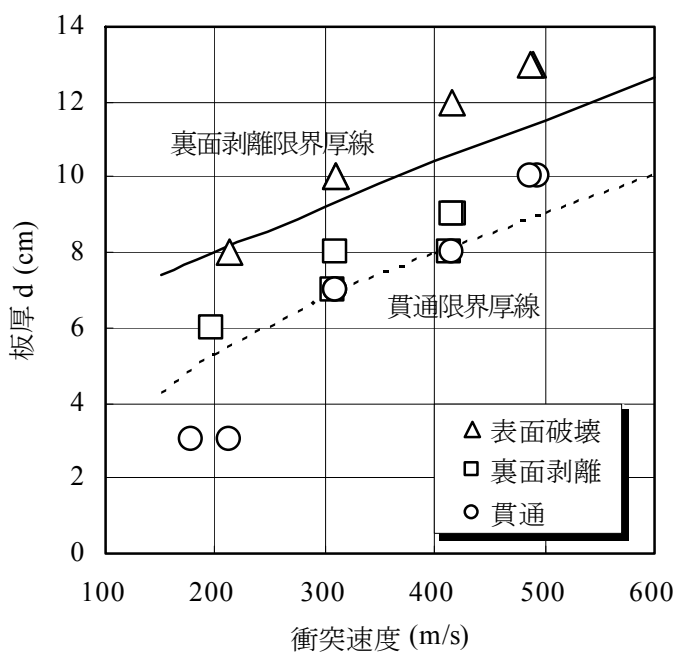

(a) 普通強度コンクリート

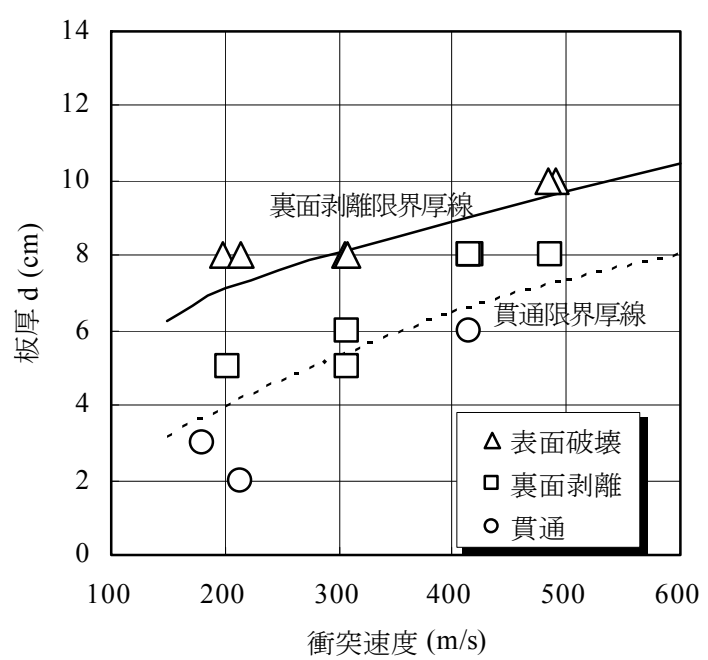

(b) 高強度コンクリート

図-7 飛翔体の衝突速度・供試体の板厚と破壊モードとの関係

正 NDRC 式は一致している。しかし，修正 NDRC 式は, 実験結果を低速度の領域ではやや安全側に, 高速度の領 域ではやや危険側に評価している. 図-7(b)の高強度コン クリートの結果では，修正 NDRC 式による貫通限界厚 は実験とほぼ一致しているが，裏面剥離限界厚は実験よ りもやや大きめの板厚となっている. 寸なわち，破壊の 進展に関しては，修正 NDRC 式は実験結果と同じ傾向 を示寸が，普通強度コンクリートに対しては進展の程度 に差異を生じ，また，高強度コンクリート材料への適用 性があまり良くないことから，今後詳細に検討する必要 があると言える.

\section{5. 表面破壊および裏面剥離の特徵}

本章では，表面破壊および裏面剥離の特徵や破壊モ 一ドが進行する条件について考察する，なお，破壊の程 度を表現する際に，図-8 に示す「板厚に対する破壊深 さの割合」を用いている，図-8(a)は表面破壊を，図-8(b) は裏面剥離を示している，図中の $\mathrm{t}_{\mathrm{s}}$ は表面破壊深さ， $\mathrm{t}_{\mathrm{r}}$ は裏面剥離深さ，d は板厚を示している. 図-8(c)に示す ように， $\mathrm{t}_{\mathrm{s}}+\mathrm{t}_{\mathrm{r}}=\mathrm{d}$ のときは，表面破壊と裏面剥離がつなが って貫通孔が生じていることを示している.

\section{（1）表面破壊の特徵}

写真-3は，飛翔体がコンクリート面に衝突して表面破 壊が生じる瞬間を高速度ビデオカメラ(10000コマ/秒)で 撮影したものである．画像の間隔は0.1msである．これ より, 飛翔体が高速で衝突すると, 衝突部近傍には粉体 となったコンクリートが飛散している様子が確認できる. その後, 飛翔体の先端はコンクリート中に貫入し, 周囲 のコンクリートが細かく破壊されていることがわかる.

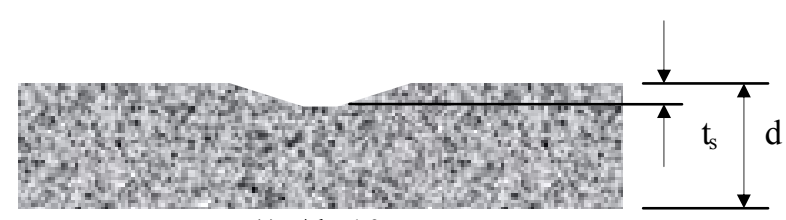

(a) $\mathrm{t}_{\mathrm{s}} / \mathrm{d}<1.0$

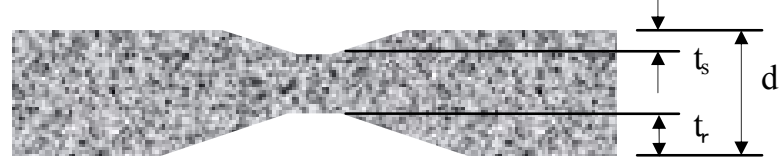

(b) $\left(\mathrm{t}_{\mathrm{s}}+\mathrm{t}_{\mathrm{r}}\right) / \mathrm{d}<1.0$
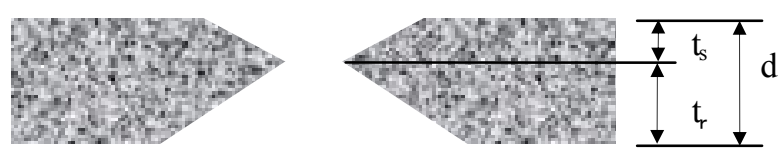

(c) $\left(\mathrm{t}_{\mathrm{s}}+\mathrm{t}_{\mathrm{r}}\right) / \mathrm{d}=1.0$

図-8＼cjkstart板厚に対する破壊深さの割合

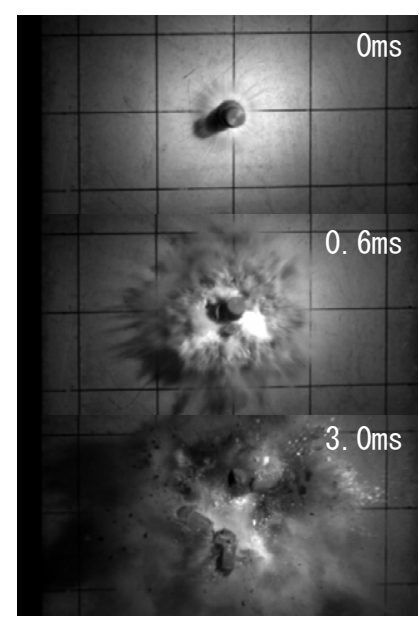

(a) 普通強度コンクリート (板厚 $7 \mathrm{~cm}$ ，衝突速度 $308 \mathrm{~m} / \mathrm{s}$ )

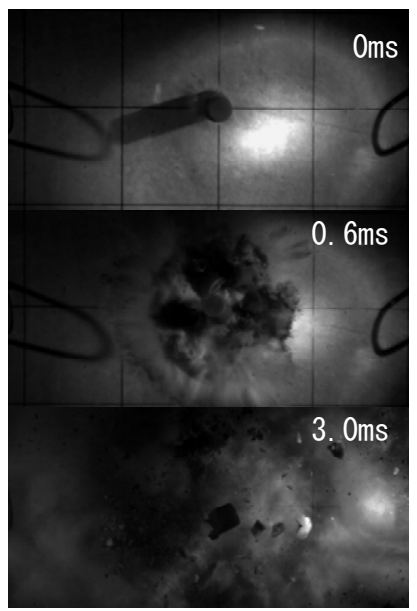

(b) 高強度コンクリート (板厚 $8 \mathrm{~cm}$ ，衝突速度 $305 \mathrm{~m} / \mathrm{s}$ )
写真-3 表面破壊が生じる瞬間 


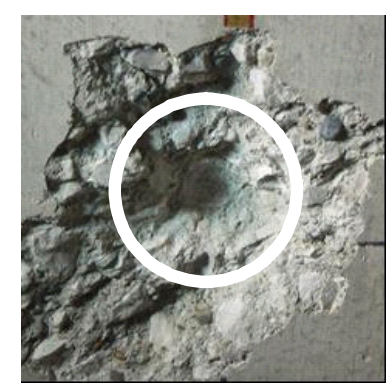

(a) 衝突部の貫入痕

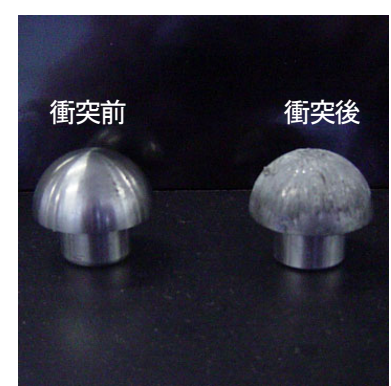

(b) 衝突前後の飛翔体

写真-4 飛翔体の高速衝突による表面破壊の貫入痕および飛翔体の損傷状況

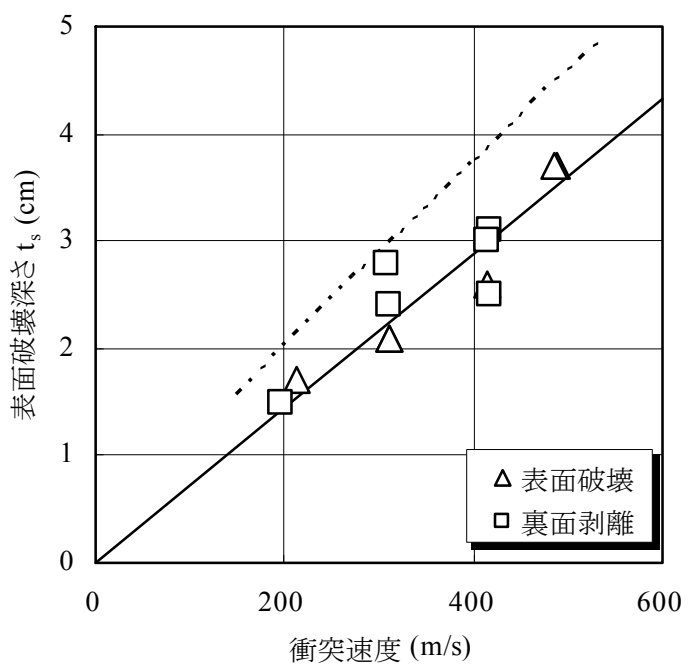

(a) 普通強度コンクリート

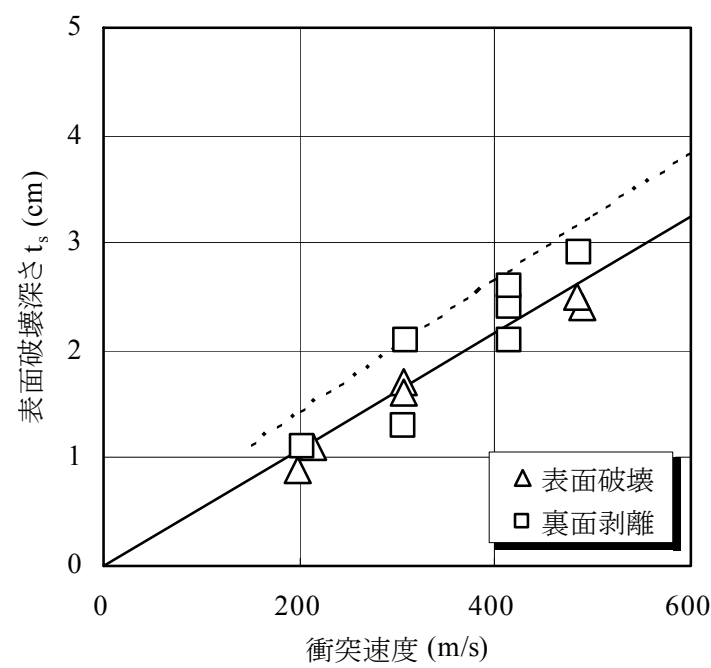

(b) 高強度コンクリート

図-9 表面破壊深さ $\mathrm{t}_{\mathrm{s}}$ 衝突速度関係

写真-4は，板厚 $9 \mathrm{~cm} の$ 普通強度コンクリート供試体に対 して速度 $417 \mathrm{~m} / \mathrm{s}$ で衝突させたケースにおいて，衝突部に 生じた飛翔体の貫入痕と飛翔体の損傷状況である．実験 後に衝突部のコンクリートを確認すると，写真-4(a)に示 すように衝突部は飛翔体が貫入した痕跡と考えられる先 端の凹部形状が残っていた. すなおち, 飛翔体はコンク リートを押し込むように進行するものと考えられる。一 方，飛翔体の表面には，写真-4(b)に示すような擦過痕が 生じているが，変形は認められなかった。

図-9に，表面破壊および裏面剥離が生じた結果に対し て得られた表面破壊深さ $\mathrm{t}_{\mathrm{s}}$ と衝突速度の関係を示す。困 中の実線は，最小自乗法により求めた回帰式で式(4a),

(4b)で表される. なお，参考のため修正NDRC式による 表面破壊深さを点線で示している.

普通強度コンクリート；

$$
t_{s}=0.0072 \mathrm{~V}
$$

高強度コンクリート；

$$
t_{s}=0.0054 \mathrm{~V}
$$

ここに， $t_{s}$ は表面破壊深さ $(\mathrm{cm}), \quad V$ は飛翔体の衝突速 度 $(\mathrm{m} / \mathrm{s})$ を示す。

図より，表面破壊深さは，強度や破壊モードによら ず，衝突速度にほぼ比例して大きくなることがわかる。 修正NDRC式と比較すると, 修正NDRC式は普通および 高強度コンクリートのいずれに対しても, 多少安全側に 評価していることがわかる. 裏面剥離にともなって生じ た表面破壊深さは，表面破壊だけが生じる場合に比べて 多少大きいが，その差異は無視できる程度である.すな わち, 本実験の範囲(飛翔体質量50g, 先端形状 : 半球, 先端径 : $25 \mathrm{~mm}$, 衝突速度 : $200 \mathrm{~m} / \mathrm{s} \sim 500 \mathrm{~m} / \mathrm{s}$ )では, 表面 破壊深さは，董面剥離にともなって生じる場合であって も，衝突速度によって決まるといえる．また，コンクリ 一ト強度の影響については, 高強度コンクリートの表面 破壊深さの方が普通強度に比べて $25 \%$ ぼ小さく, 高強 度化するほど表面破壊の程度を軽減させる効果がある。 


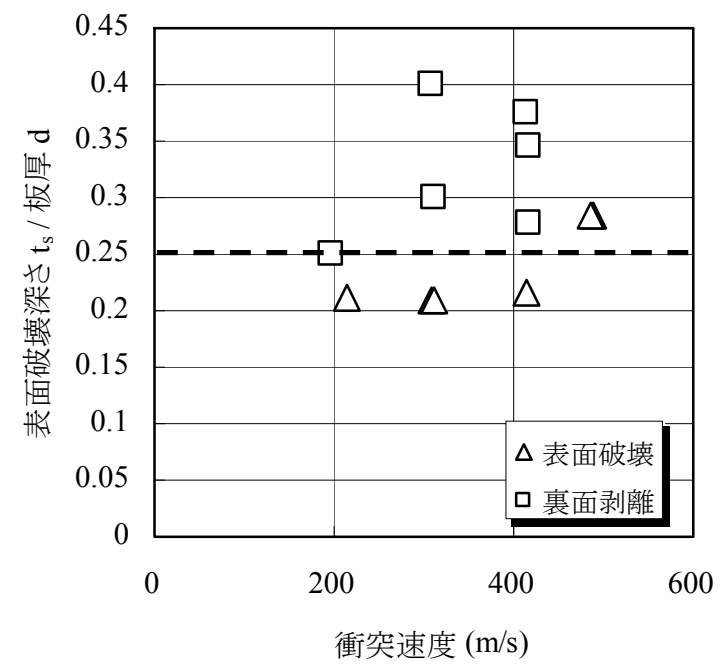

(a) 普通強度コンクリート

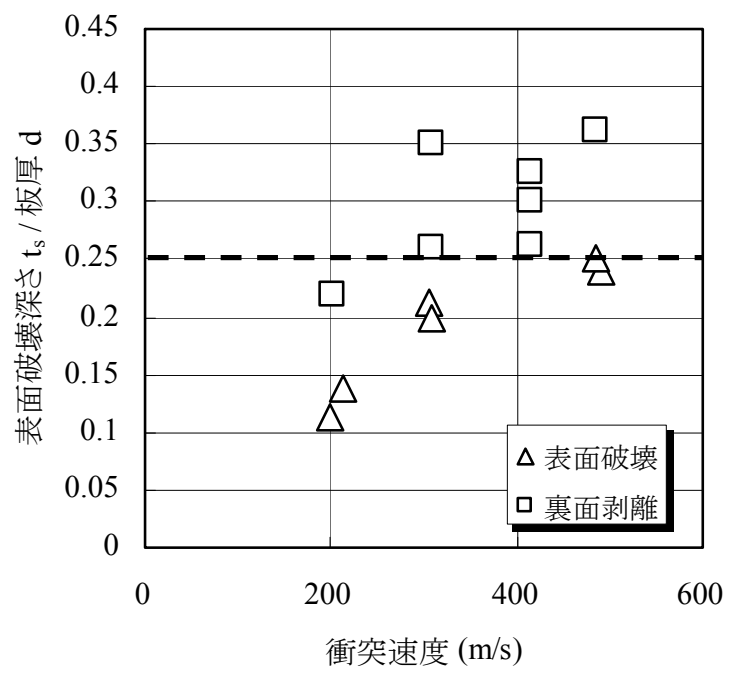

(b) 高強度コンクリート

図-10 表面破壊深さ t $\mathrm{t}$ 板厚 $\mathrm{d}$ 衝突速度関係

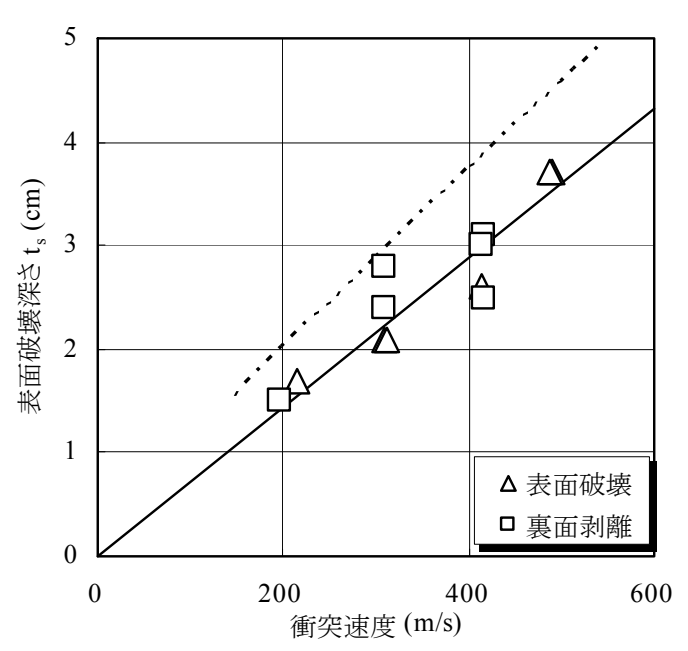

(a) 普通強度コンクリート

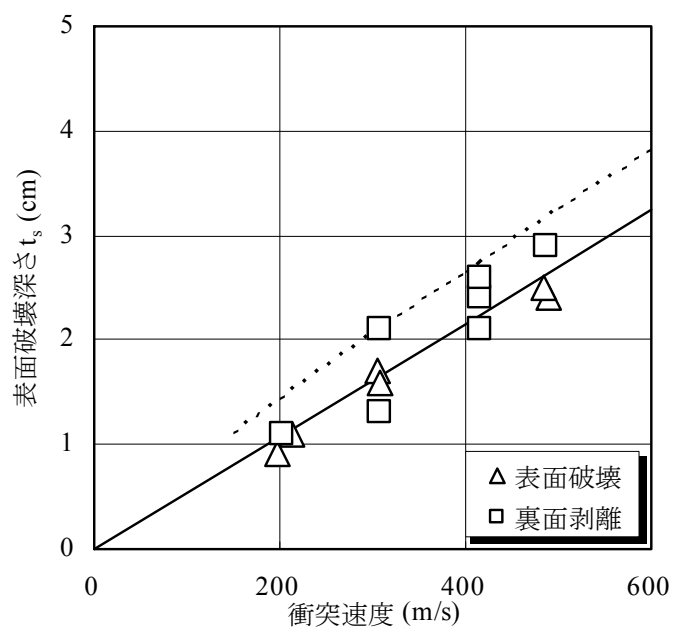

(b) 高強度コンクリート

図-11 表面破壊直径〜表面破壊深さ $\mathrm{t}_{\mathrm{s}}$ 関係

次に，図-10に，表面破壊深さを板厚で除した相対表 面破壞深さと衝突速度の関係を示す，これより，普通強 度および高強度コンクリートのいずれも，衝突速度に関 係なく, 表面破壊深さが板厚の約24〜27\%を超えると破 壊モードが表面破壊から裏面剥離へ移行することがわか る. このように, 表面破壊深さの大きさは裏面剥離の発 生に影響していると考えられる.

表面破壊の直径と深さの関係を，図-11に示す，図中 の実線は，最小自乗法により求めた回帰式で式(5a)，(5b) で表される.

普通強度コンクリート；

$$
C_{d}=5.11 t_{s}
$$

高強度コンクリート；

$$
C_{d}=6.41 t_{s}
$$

ここに， $C_{d}$ は表面破壊直径 $(\mathrm{cm})$ を示寸

これより, 表面破壊の直径は, 表面破壊深さにほぼ比 例して大きくなることがわかる，また，表面破壊深さが 等しい場合は, 高強度コンクリートに生じる破壊直径が 大きくなることがわかる.

\section{（2）裏面剥離の特徵}

写真-5に, 高速度ビデオカメラで撮影した裏面剥離時 の破壊挙動を示寸。普通強度および高強度コンクリート 供試体の板厚はそれぞれ $9 \mathrm{~cm}$ と $8 \mathrm{~cm}$ で，衝突速度はいず れも約 $420 \mathrm{~m} / \mathrm{s}$ である.

写真-5から，普通強度コンクリートの場合は衝突 $(\mathrm{t}=0.0 \mathrm{~ms})$ 後 $\mathrm{t}=0.1 \mathrm{~ms}$, 高強度コンクリートではt $=0.2 \mathrm{~ms}$ 以内 にひび割れが裏面に発生していることがわかる，破壊の 


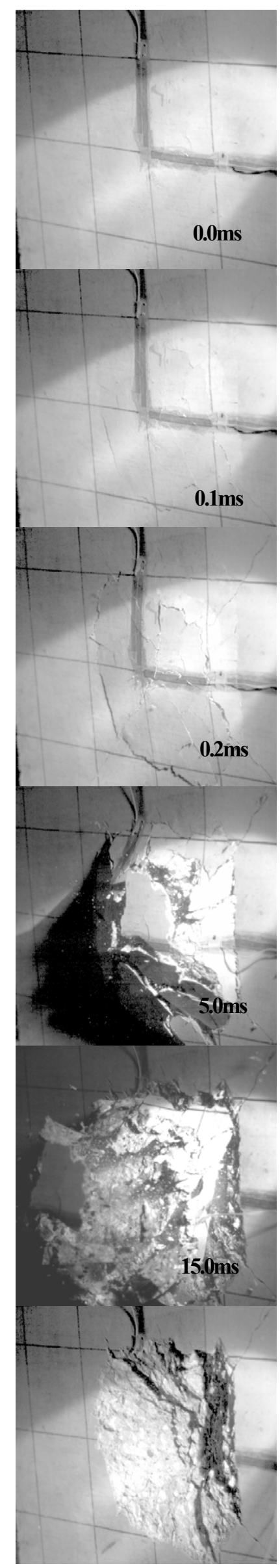

(a) 普通強度コンクリート

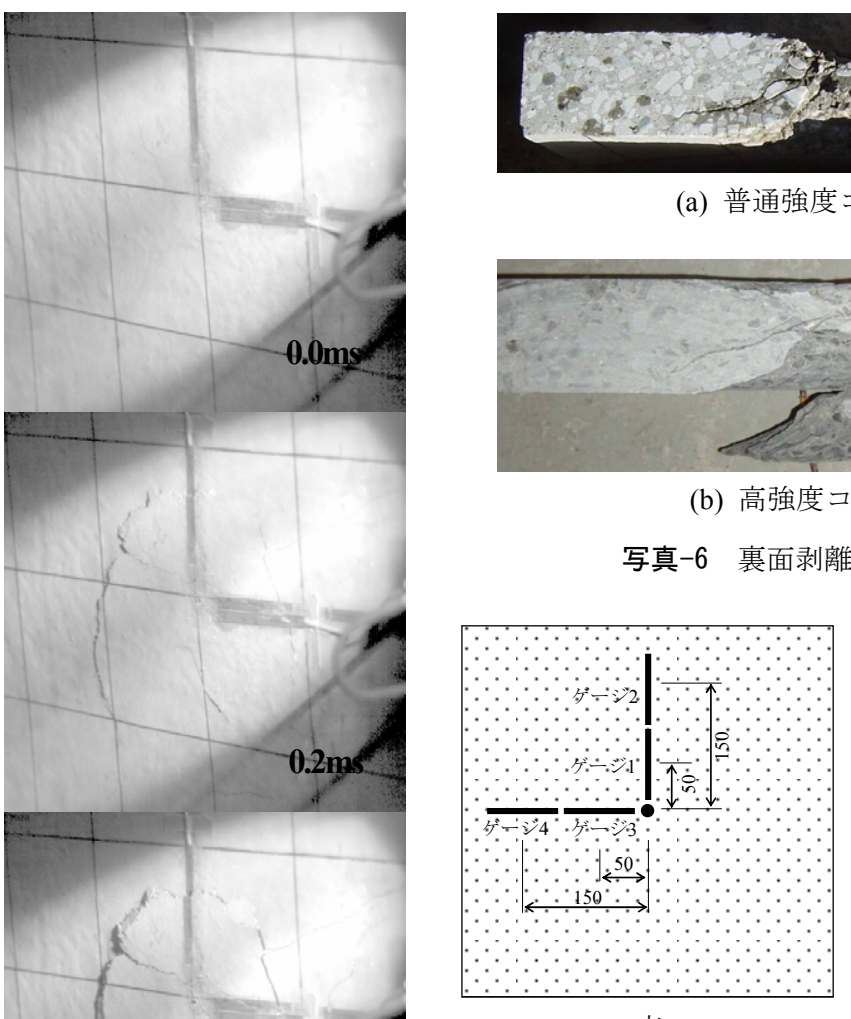

表

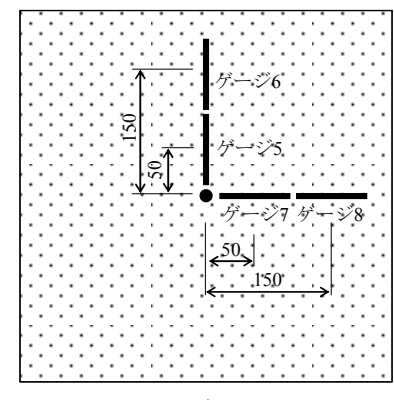

裏

図-12 表面および裏面に設置したひずみゲージの位置

状況をみると，普通強度コンクリートの場合は，裏面に 多くのひび割れが発生した後, 破片化して飛散している 様子がわかる．一方，写真-5(b)の高強度コンクリートの 場合は，破壊が脆性的に発生しており，破壊片は比較的 大きな塊として後方に押し抜かれる特徵がある. 写真-6 は，供試体の衝突部断面を実験後に切断したものである. これより, 普通強度, 高強度コンクリートとともに, 供 試体内部には大きく発達したひび割れが確認できる.

また，図-12に示すように，供試体表面および裏面に おいて，板中央から直交する二方向に長さ $8 \mathrm{~cm}$ のずみ ゲージを各2枚貼付した．図-13に，供試体表面に貼付し たひずみゲージの応答を示す．図-13(a)に示す普通強度 コンクリート板の表面のひずみ応答から，衝突中央部に 近いひずみゲージ1，3は，飛翔体の衝突直後に破断して いることがわかる．中央部から $100 \mathrm{~mm}$ 離れた位置に貼付 したひずみゲージ2，4では，衝突後時刻0.1msで約 $220 \mu$ の最大圧縮ひずみが生じている，一方，図-13(b)に示す 高強度コンクリートの場合は，衝突中央部に近いひずみ ゲージ1では時刻 $0.03 \mathrm{~ms}$ で約 $1100 \mu$ ，ひずみゲージ3では 時刻 $0.02 \mathrm{~ms}$ で約 $300 \mu$ の最大圧縮ひずみが生じた後に破 断していることがわかる. 中央部から100mm離れたひず

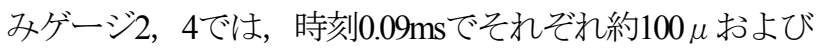
$250 \mu$ の第1ピークの圧縮ひずみを示した後に減少・増加 して，ひずみゲージ2は時刻 $0.2 \mathrm{~ms}$ で最大圧縮ひずみ 500 $\mu$ を示している. その後は, 圧縮ひずみが減少して引張 


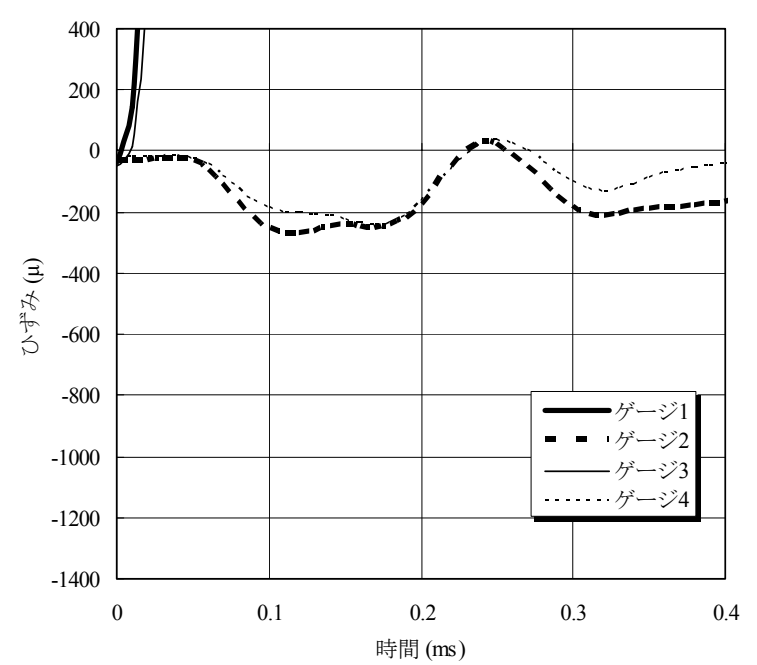

(a) 普通強度コンクリート

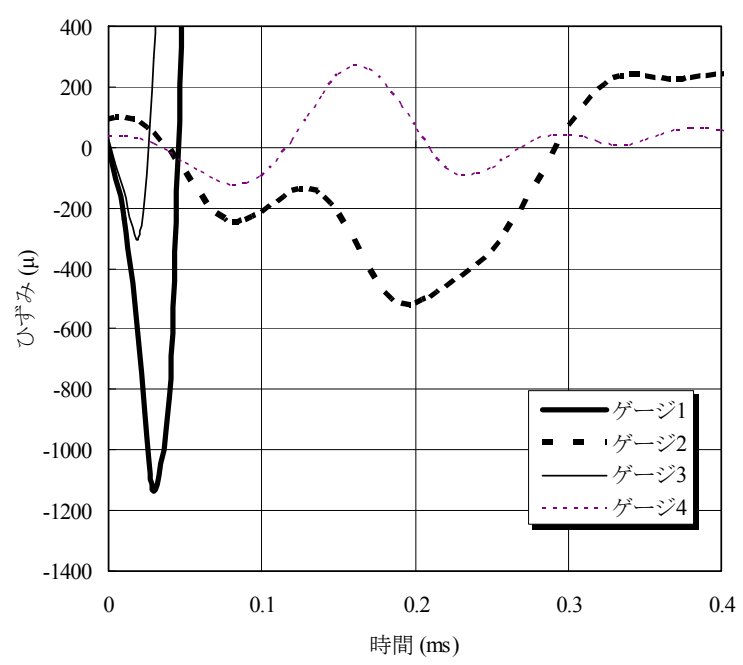

(b) 高強度コンクリート

図-13 表面のひずタ〜時間関係

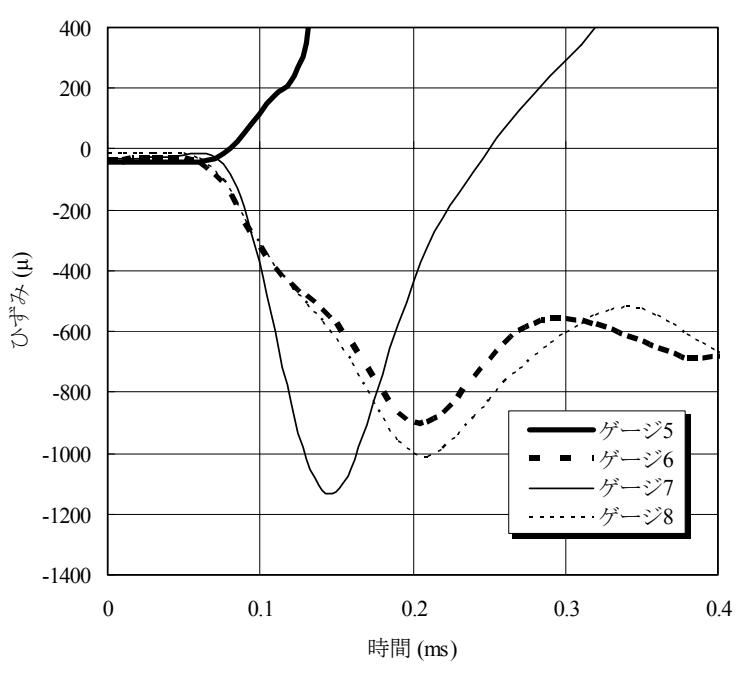

(a) 普通強度コンクリート

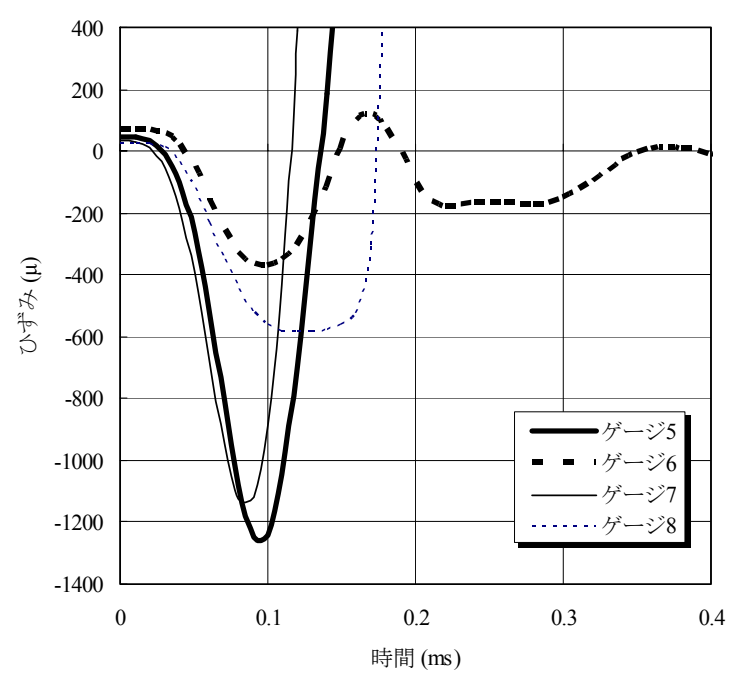

(b) 高強度コンクリート

図-14 裏面のひずみ〜時間関係

ひずみに転じている.

次に，図-14に董面におけるひずみ応答を示す。図一 14(a)の普通強度コンクリート供試体の場合は，中央部に 近いひずみゲージ5，7は衝突後，約0.05〜0.06ms後にひ ずみ応答が検出され始めている。 また，ひずみゲージ7 では時刻 $0.14 \mathrm{~ms}$ で約 $1200 \mu$ の最大圧縮ひずみを生じた後, 引張側に転じて引張破断した。ひずみゲージ5は計測不 良であった。 なお， 中央から150mm離れた位置にあるひ ずみゲージ6，8はほぼ等しい挙動を示し，時刻 $0.2 \mathrm{~ms}$ 最大圧縮ひずみは約 $900 〜 1000 \mu$ である. 一方，図-14(b) に示す高強度コンクリート供試体では，飛翔体の衝突後 約 $0.03 \mathrm{~ms}$ 後に裏面にひずみが生じている. 中央部のひず みゲージ5，7は時刻 $0.09 〜 0.1 \mathrm{~ms}$ で約 $1100 \sim 1200 \mu$, 中央 から150mm離れたひずみゲージ6は同時刻で約400 $\mu$ ，ひ ずみゲージ8は約600 $\mu$ の最大圧縮ひずみが生じ，その後 約0.1ms後にひずみゲージ5, 7は引張破断した.
波動論によれば，コンクリート中の弾性波速度は, 一次元の場合に $c=\sqrt{E / \rho}$ で与えられる. ここで, 普通 強度コンクリートの縦弾性係数は $\mathrm{E}=25 \mathrm{kN} / \mathrm{mm}^{2}$, 密度は $\rho=2.5 \mathrm{~g} / \mathrm{cm}^{3}$ なので，弾性波伝播速度は $\fallingdotseq 3000 \mathrm{~m} / \mathrm{s}$ となる. したがって，板厚 $\mathrm{t}=9 \mathrm{~cm}$ では，応力波が表面から裏面一 伝わる時間は理論上 $\mathrm{t} / \mathrm{c}=9(\mathrm{~cm}) / 3000(\mathrm{~m} / \mathrm{s})=3 \times 10^{-5} \mathrm{~s}=0.03 \mathrm{~ms}$ ある. 計測したひずみの方が理論で仮定した波動伝播 の方向と直交していること，およびひずみの值は区間 $8 \mathrm{~cm}$ の平均值であるため, 理論による応力波の到達時間 とは多少のずれがあるが，この時間は，普通強度コンク リート板の裏面にひずみが明瞭に生じ始めた時刻 $0.05 \mathrm{~ms}$ に近い值である. すなわち, 飛翔体の衝突によって表面 に生じた圧縮応力波は, 裏面に到達し, 裏面の自由端で 反射して引張応力に転じたものと考えることができる.

しかし，図-14から，ひび割れ発生ひずみを $100 \mu$ とする と，裏面にひび割れが生じる時間は衝突後約 $0.12 〜$ 


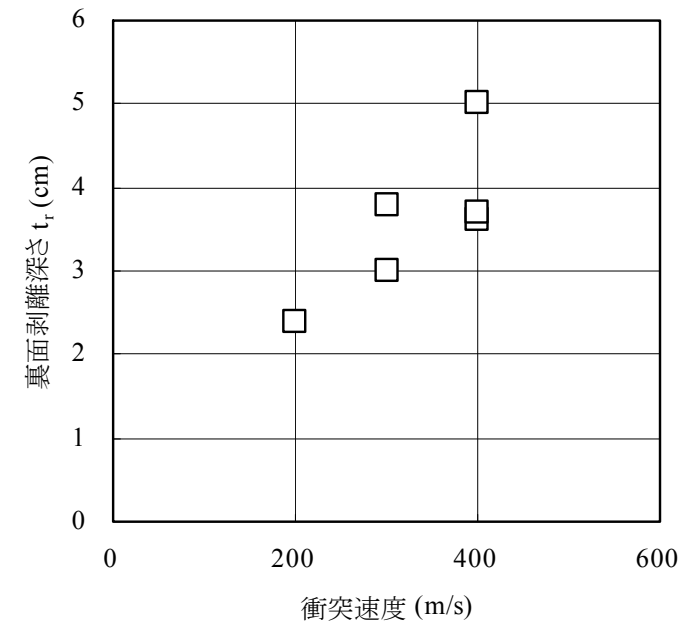

(a) 普通強度コンクリート

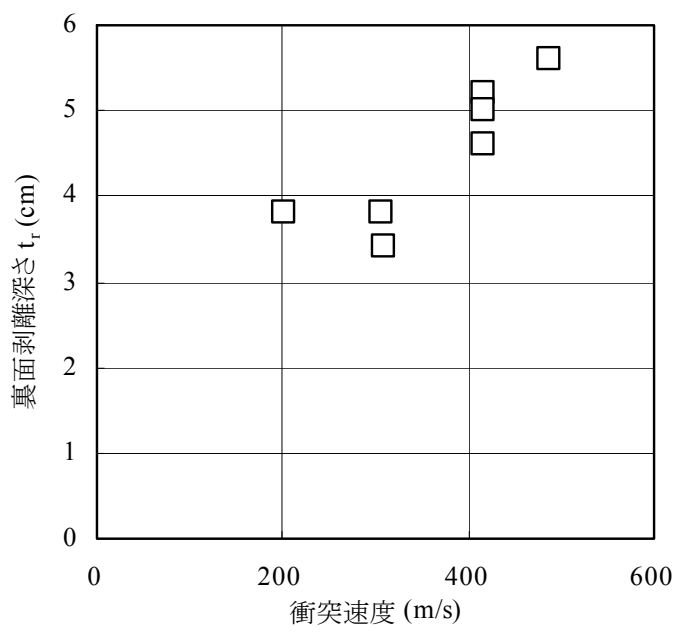

(b) 高強度コンクリート

図-15 裏面剥離深さ $\mathrm{t}_{\mathrm{r}}$ 衝突速度関係

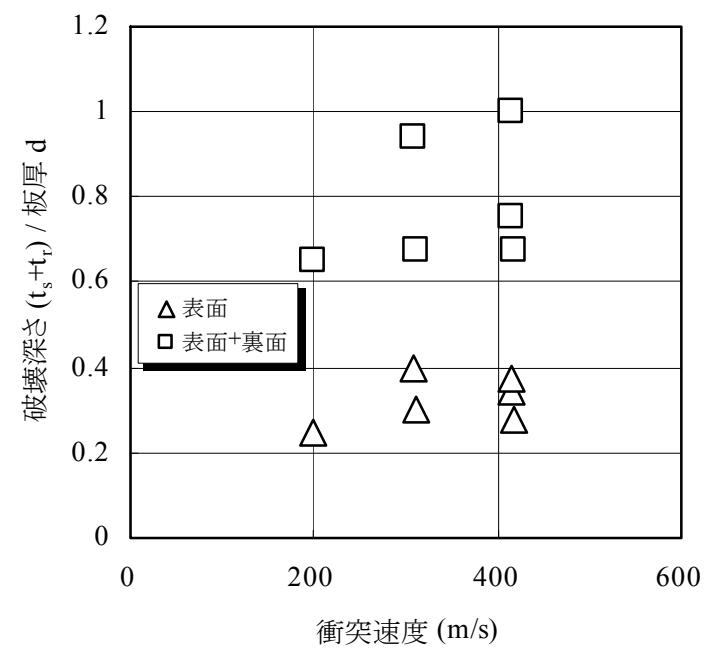

(a) 普通強度コンクリート

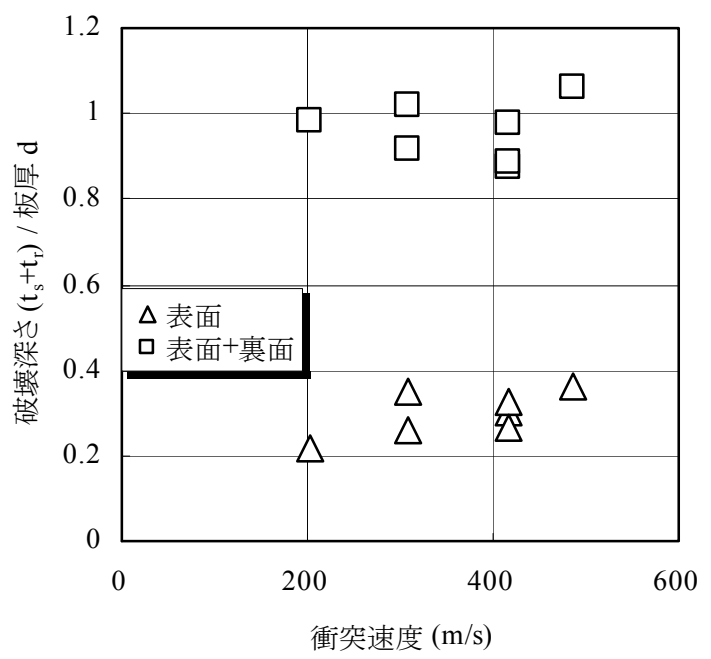

(b) 高強度コンクリート

図-16 破壊深さ $\left(\mathrm{t}_{\mathrm{s}}+\mathrm{t}_{\mathrm{r}}\right)$ 板厚 $\mathrm{d} \sim$ 衝突速度関係

0.26msである，すなわち，裏面に発生した大きな剥離破 壊は，応力波が伝播した直後に生じたのではなく，波動 が板厚を2４往復する程度の時間を経過して破壊したこ とを示している。ちなみに，図-14(b)に示したひずみ $(\varepsilon)$ 〜時間(t)関係から最大圧縮ひずみに到達するまでのひず 夕速度 $(\dot{\varepsilon}=d \varepsilon / d t)$ を求めると，10 $10^{2}(1 / \mathrm{s})$ であること がわかる。

図-15は，董面剥離深さと衝突速度の関係を示してい る. 図より, 普通および高強度コンクリート供試体のい ずれにおいても, 衝突速度の増加にともなって裏面剥離 深さが増大することがわかる。

図-16は，裏面剥離が生じたケースにおいて生じた 「表面破壊深さ $\mathrm{t}_{\mathrm{s}} 」$ と「表面破壊深さ $\mathrm{t}_{\mathrm{s}}+$ 裏面剥離深さ $\left.\mathrm{t}_{\mathrm{r}}\right\rfloor$ を，板厚に対する相対的深さとして示したものである. 図-16から，普通強度コンクリートでは，表面破壊深さ の割合は衝突速度によらず0.24〜0.39の間でほぼ一定值
を示し, 衝突速度の増加とともに裏面剥離深さだけが 徐々に増加していることがわかる，一方，高強度コンク リートの場合は表面破壊の割合は普通強度と同様に，衝 突速度によらず0.21〜0.37の間で一定值を示すが，(表面 破壊深さ $\mathrm{t}_{\mathrm{s}}+$ 裏面剥離深さ $\mathrm{t}_{\mathrm{r}}$ ) 板厚 $\mathrm{d}$ はどのケースも 1.0 に極 めて近接している. すなわち, 裏面剥離が生じる場合, 裏面における破壊の割合は普通強度に比べて大きく, 一 挙に貫通寸前まで至ることがわかる. なお，(表面破壊 深さ $\mathrm{t}_{\mathrm{s}}+$ 裏面剥離深さ $\mathrm{t}_{\mathrm{r}}$ ) 板厚 $\mathrm{d}$ が1.0を超えたケースもある が，これは測定上の誤差である.

図-17は，董面剥離あるいは貫通孔が生じた場合にお いて, 裏面剥離深さを板厚で除した相対裏面剥離深さと 衝突速度の関係を示している. 図中の点線は, 相対裏面 剥離深さの下限と上限を示している. この関係から, 裏 面剥離だけが生じた場合の最小相対裏面剥離深さは，普 通強度コンクリートでは板厚の約 $40 \%$, 高強度コンクリ 


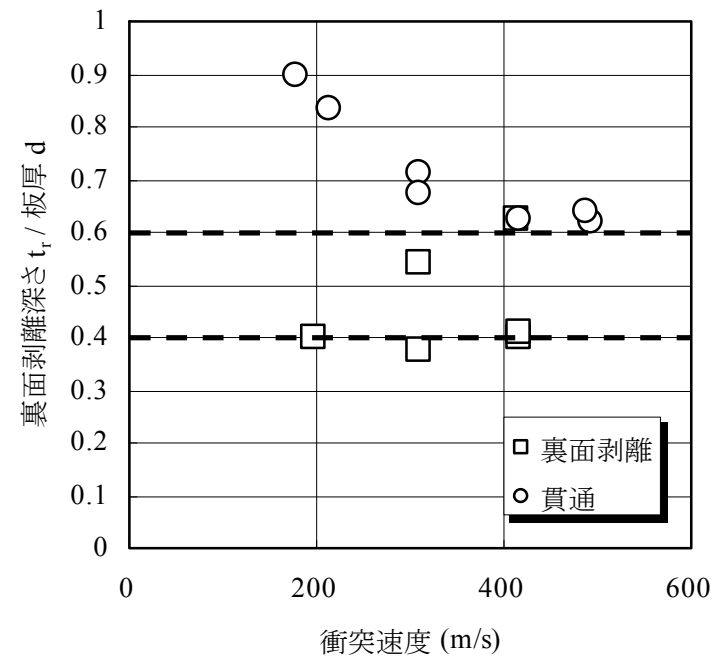

(a) 普通強度コンクリート

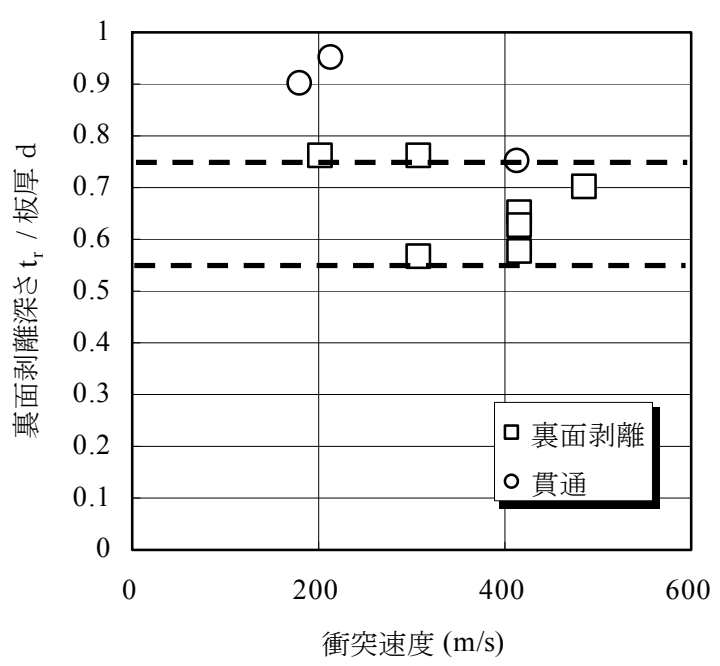

(b) 高強度コンクリート

図-17 董面剥離深さ $\mathrm{t}_{\mathrm{P}}$ 板厚 $\mathrm{d}$ ～衝突速度関係

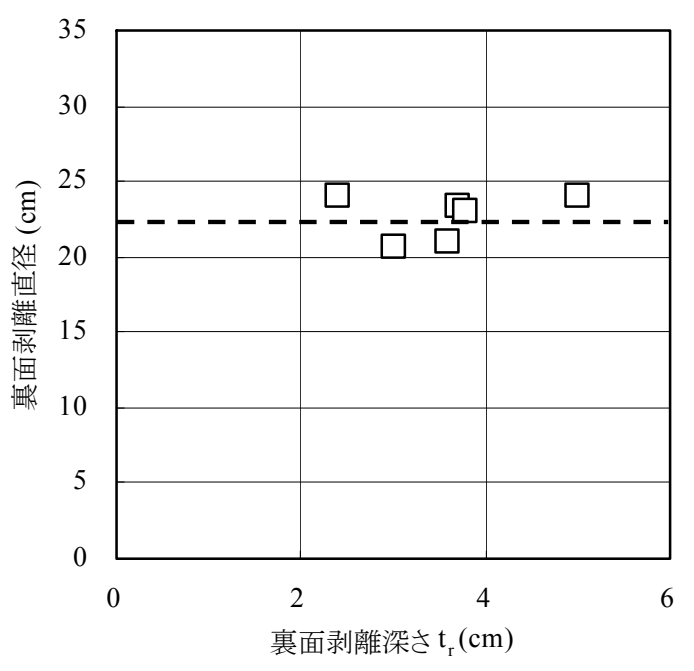

(a) 普通強度コンクリート

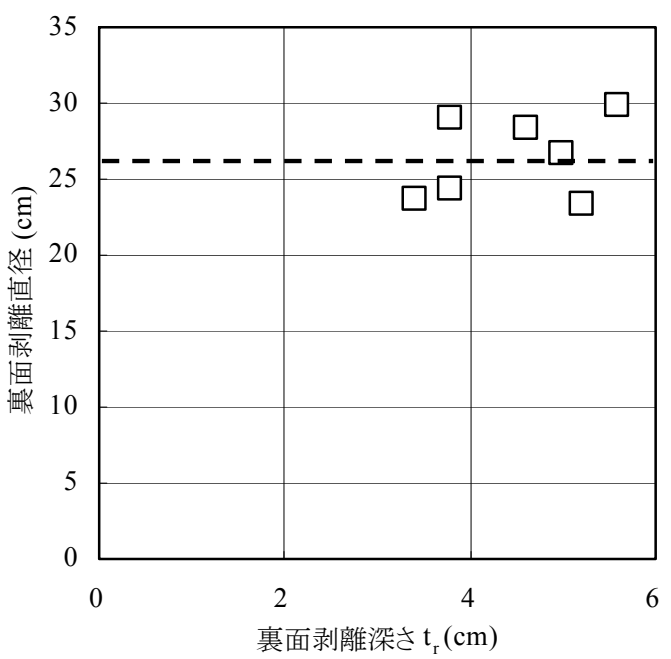

(b) 高強度コンクリート

図-18 裏面剥離直径〜裏面剥離深さ $\mathrm{t}_{\mathrm{r}}$ 関係

一トの場合では約55\%である，すなわち，裏面剥離が生 じる場合は，少なくとも板厚の $1 / 2$ 程度の裏面剥離深さ になることを示している，また，普通強度コンクリート では，相対裏面剥離深さが板厚の約 $60 \%$ を超えると，表 面破壊と裏面剥離が連なって貫通孔が生じることがわか る. 一方, 高強度コンクリートの場合は, 相対裏面剥離 深さが板厚の約75\%を超えると貫通孔が生じる.

図-18は，裏面剥離の直径と深さの関係を示している. 図中の点線は, 裏面剥離直径の平均值を示している. 図 から, 裹面剥離が生じる場合は，コンクリートの強度に よって異なるが，裏面剥離の直径はほぼ一定となり，普 通強度で約 $22.5 \mathrm{~cm}$, 高強度では約 $26 \mathrm{~cm}$ であった. 寸なわ ち, 高強度コンクリートの方が普通強度コンクリートよ り引張強度が大きいので裏面剥離は生じにくいが，破壊 が生じた場合には表面破壊と同様に，高強度コンクリー 卜の方が破壊の直径も大きくなることがわかる.
以上より, 破壊の程度の相違の条件をまとめると次 のようになる。(1)飛翔体が衝突して表面破壊が板厚の 約 $25 \%$ を超えると裏面剥離が発生するが，このときの裏 面剥離深さは板厚の約40～55\%である. つまり，この時 点で板厚に対して約65～80\%の破壊深さが生じることに なる。ささらに(2)衝突速度が大きくなって裏面剥離深さ が増大寸ると，最終的に貫通破壊が発生するものと考え られる。.また，(3)コンクリート強度による局部破壊の 違いについては, 高強度コンクリートは表面破壊に対す る抵抗力は大きく, 裏面剥離も普通強度コンクリートに 比べて発生しにくいが, 裹面剥離が発生する場合は貫通 寸前であることがわかった，この理由は，(1)高強度コ ンクリートは普通強度コンクリートに比べて脆性的であ ること，また(2)表面破壊には主として圧縮で, 裏面剥 離には引張で抵抗すると考えられるが, 高強度コンクリ 一トは, 普通強度コンクリートに対寸る圧縮強度の増加 
率に比べて引張強度の増加率が小さいことに起因すると 考えられる. また, 貫通が生じる(生じやすい)のは, 裏 面剥離によって板の有効厚さが減少することと関係して いる.

したがって, 裏面剥離の発生を防止又は抑止するこ とにより, 板の貫通抵抗性を向上させることができる.

この方法としては, コンクリート板の高強度化により表 面破壊を低減させることや，コンクリート板の厚さを増 加する，あるいは裏面にライナ一等を貼付する方法によ り，裏面剥離を抑制することなどが考えられる.

\section{6. 結言}

本研究は，鋼製剛飛翔体の高速衝突を受けるコンク リートの局部破壊について実験的検討を行い, 衝突速度 および板厚と破壊モードの関係を調心゙, 破壊の特徴につ いて検討を行ったものである. 本研究の成果を要約する と，以下のようになる。

（1）鋼製の飛翔体(質量 $50 \mathrm{~g} \sim 1000 \mathrm{~g}$ )を $100 \sim 500 \mathrm{~m} / \mathrm{s}$ の速度 で発射できる高圧空気式飛翔体発射装置を開発し, 普通強度および高強度コンクリートの板供試体に 対する衝突実験を行った。 その結果, 飛翔体の衝 突速度が大きく, また, 板厚が小さくなるにした がって, 破壊が表面破壊, 裏面剥離, 貫通の順に 大きくなる.

（2）表面破壊深さは，破壊モードにかかわらず飛翔体 の衝突速度に比例して大きくなる.また，コンク リート強度および衝突速度に関係なく, 表面破壊 深さが板厚の約 $25 \%$ を超えると裏面剥離が生じる.

(3) 裏面剥離深さは, 表面破壊深さや板厚の影響を受 けるが, 少なくとも板厚の半分程度の深さが生じ る.

（4）コンクリート強度の高強度化は，局部破壊の防止 に効果がある. すなわち, 圧縮強度の増加にとも ない表面破壊に対する抵抗力は増大寸るとともに, 引張強度も大きくなるので裏面剥離も発生しにく い. ただし，高強度コンクリートの場合，破壊が 生じる際は普通強度コンクリートよりも脆性的な ため, 裏面に生じる破壞(直径, 深さ)は, 普通強度 コンクリートに比べて大きくなる.

（5）局部破壊の抑止方法については，(1)表面破壊に対 してはコンクリート強度を増加させること，(2)裹 面剥離に対してはコンクリートの強度および板厚 を増加させる, あるいは板の裏面にライナー等を 貼付してコンクリートの引張強度を改善すること, (3)貫通には裹面剥離を防止すること, 等が考えら
れる。

今後は, 表面破壊や裏面剥離の発生メカニズムや飛翔 体の質量, 先端形状, 岡性が破壊に与える影響について 調べていくとともに数值シミュレーション法の検討を行 う必要があると考えている.

\section{参考文献}

1) 上原陽一監修: 防火・防爆対策技術ハンドブック, 株式会 社テクノシステム, 2004.

2) 北川徹三 : 爆発災害の解析, 日刊工業新聞社, 1980.

3) (社)火薬学会 発破専門部会: 発破工学ハンドブック, 共 立出版, 2001.

4) Kennedy, R.P. : A review of procedures for the analysis and design of concrete stuctures to resist missile impact effects, Nuclear Engineering and Design, 37, pp.183-203, 1976.

5) Sliter, G.E. : Assessment of empirical concrete impact formulas, ASCE, Vol.106, No.ST5, pp.1023-1045, 1980.

6) 土木学会衝撃問題研究小委員会: 構造物の衝撃挙動之設計 法, 土木学会構造工学シリーズ6, pp.275〜292, 1994.

7) 電力中央研究所 : 飛来物の衝突に対するコンクリート構造 物の而衝撃設計手法, 電力中央研究所報告, 1991.

8) 電力中央研究所 : 高速飛来物に対する鉄筋コンクリート構 造物の設計評価式, 電力中央研究所報告, 1988.

9）伊藤千浩, 白井孝治, 大沼博志 : 剛飛来物の衝突に対する 鉄筋コンクリート構造物の設計評価式, 土木学会論文集,

No.507/ I -30, pp.201 208, 1995.

10）内田孝，大野友則 : 柔飛翔体の高速衝突による鉄筋コンク リート版の局部損傷の予測, 防衛大学校理工学研究報告,

Vol.29, No.2, pp.209 217, 1992.

11) 内田孝, 大野友則 : 航空機ジェットエンジンの高速衝突を 受ける鉄筋コンクリート版の衝撃応答とその予測に関する 研究, 日本建築学会構造系論文集, No.471, pp.81 89, 1995.

12) Gareth, H. : Hard missile impact on reinforced concrete, Nuclear Engineering and design, 77, pp.23-35,1984.

13) Chang, W.S.: Impact of solid missiles on concrete barriers, ASCE, Vol.107,No. ST2,pp.257-271, 1981.

14) 大野友則 : 飛翔体の衝突に対するRC版の挙動に関する研究 の現状，コンクリート工学, pp.20〜28, Vol.41，No.4, 2003.

15) Itoh, M., Katayama, M. and Rainsberger, R. : Computer simulation of an F-4 phantom crashing into a reinforced concrete wall, Computational Ballistics II, pp.207-217,2005.

16) Goldsmith, W:: Non-ideal projectile impact on targets, Intemational Journal of Impact Engineering, 22, pp.95-395, 1999.

(2006.9.19受付) 


\title{
AN EXPERIMENTAL STUDY ON THE LOCAL DAMAGE OF CONCRETE PLATE DUE TO HIGH VELOCITY IMPACT OF STEEL PROJECTILE
}

\author{
Masuhiro BEPPU, Koji MIWA, Tomonori OHNO and Masanori SHIOMI
}

The local damage due to high velocity impact of steel projectile on concrete plate was experimentally studied. To execute the impact tests, the air-pressurized launching apparatus is newly developed. This apparatus was designed to launch a projectile with the velocity of $100-500 \mathrm{~m} / \mathrm{s}$ corresponding to the mass of $50-1,000 \mathrm{~g}$. Targets are square plate $(500 \times 500 \mathrm{~mm}$ in size) and are the standard and high-strength concrete (the compressive strength of $25 \mathrm{~N} / \mathrm{mm}^{2}$ and $100 \mathrm{~N} / \mathrm{mm}^{2}$, respectively). During all tests, the appearance of local damage in the impacted point was taken by an ultra-high speed video camera. From test results, the effect of impact velocity of projectile on the local damage was examined with the relation of plate thickness of specimen and the strength of concrete. And, the damage process was discussed through the size of local damage in depth and diameter. 